\title{
Evaluation of Microbiological Quality of Commercially Available Bottled Water in the City of Dhaka, Bangladesh
}

\author{
Ahmad Kamruzzaman Majumder, ${ }^{1 \ddagger}$ K. M. Nazmul Islam, ${ }^{2}$ Rezwanun Naher Nite, ${ }^{1}$ and Rashed Noor ${ }^{3}$ \\ ${ }^{1}$ Department of Environmental Science, Stamford University Bangladesh, ${ }^{2}$ Institute of Forestry and Environmental \\ Sciences, University of Chittagong, ${ }^{3}$ Department of Microbiology, Stamford University Bangladesh
}

Received 18 Dec 2010/Accepted 14 Feb 2011

\begin{abstract}
Bottled water has become one of the most popular drinks in Bangladesh. Now a days it is easily available in the market. Due to lack of confidence on municipal supply water, people now prefer to drink bottled water instead of tap water, mostly when they are outside the home, and in many occasions. In the present study, the presence of total coliforms (TC) and fecal coliforms (FC) from nine commercially available lacal Bangladeshi bottled water samples were examined. The obtained results indicated that most of the studied bottled water were out of their safety guidelines and hence some chronic diseases (renal failure, liver cirrhosis and anemia) are expected in the area understudy, because $68.89 \%$ and $31.11 \%$ of the bottled water sampled in the current study showed heterotrophic plate counts (HPC) within a range of 1-500 (cfu/ml) and greater than 500 (cfu/ml), respectively and $0 \%$ samples showed less than 1 (cfu/ml) in heterotrophic plate counts. The results also revealed the ill performance and poor drinking water quality of the purification systems of the investigated water samples. $28 \%$ of the respondents considered that the quality of bottled water was satisfactory, in contrast to the $26 \%$ of the respondent, who judged that the quality of bottled water was not that satisfactory. However, the highest (34\%) number of the respondents did not know whether the quality of the bottled water is good or not satisfactory. Recommendation was suggested for new treatment systems of the investigated suspicious water to prevent human illness.
\end{abstract}

The past few decades have experienced a dramatic increase in the consumption of bottled and, more especially, plastic container drinking water in Bangladesh. The increase in demand for these corporate labeled water products is driven by few factors like changes in fashion towards the consumption of designer water; increased concerns about the contamination of the piped water supply; and an increased influx of people into the major shopping areas and some fast food shop as well as restaurant, with a requirement for good drinking water $(1,2)$. At present, there is inadequate information on the microbiological quality of these water products and it is important that the consumers can be assured of their quality and safety. The transmission of waterborne diseases is still a matter of major concern, despite worldwide efforts and modern technologies are being utilized for the production of safe drinking water (3). This problem is not only confined to the developing world where water treatment may not exist or is inadequate, but also in some developed countries. There may also be contamination during storage, a lack of regulations and limited understanding and awareness among the population (4).

Water consumed by human beings comes in various

${ }^{\ddagger}$ Corresponding Author. Mailing address: Dr. Ahmad Kamruzzaman Majumder, Dept. of Environmental Science, Stamford University Bangladesh, 744, Satmosjid Road, Dhanmondi, Dhaka, Bangladesh, Phone: +88-02-8156122, Email: kamrul_sub@hotmail.com.

\section{The usage of Bottled water in The World}

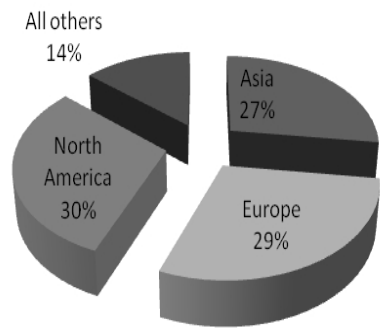

FIG.1. Usage of bottled water throughout the World (5)

forms and from various sources (6). Recently, popularity of bottled mineral water with consumers has increased dramatically due to the ever-increasing contamination of water resources. Mineral water always contains various minerals and trace elements $(7,8)$ and can be defined as water containing minerals which are natural compounds formed through geological processes or other dissolved substances that alter its taste or give it therapeutic properties; alternatively, it is the act of remediation of a health problem after diagnosis. Minerals are required by human beings for nutrition, growth, sustaining body functions and well-being. Concentrations of minerals depend highly upon various factors. These minerals have various effects on the health of a person (9-11). 
It is reported that the natural concentrations for many elements span several orders of magnitude due to the sources' geological background, landforms and use of land (12) and anthropogenic activities $(13,14)$. Mineral water is actually based on a minimum concentration of dissolved salts. Despite the fact that many Western European nations enjoy a percentage compliance rate in the high 90s for their tap water; the mineral water industry has been very successful in marketing mineral waters as 'better drinking water'. Yet, in the United States, for example, the proportion of waterborne disease outbreaks linked with problems in public water distribution systems has been noted to be on the increase $(15,16)$. Such examples convince the public to use bottled water.

\section{MATERIALS AND METHODS}

A total of 45 samples of bottled water of 9 different brands (5 for each brand), produced domestically and distributed all over the country, were collected randomly from retail shops in the metropolitan city of Dhaka from October to November 2009. Each sample was analyzed both quantitatively and qualitatively. Quantitative analysis was based on total coliforms (TC) count, and fecal coliforms (FC) count. Samples (100ml) were filtered through membrane filters with pore size of $0.45 \mu \mathrm{m}$ and the filters were placed on MacConkey agar and mFC agar for total coliform and fecal coliform, respectively. The plates were incubated for 24 hours at required temperature $\left(37^{\circ} \mathrm{C}\right)$. After incubation colonies were counted manually. To acquire a public perception regarding bottled water in Bangladesh, a questionnaire survey was designed. The sample number of the survey was 50. For data processing, the software Microsoft Excel 2007 and SPSS16 were used.

\section{RESULTS}

Microbial enumeration. The outcome of microbiological analysis performed on samples from the one liter bottled water of different brands collected from the domestic markets of Dhaka city, Bangladesh appears in tables 2, 3 and 4. As per World Health Organization (WHO) and Bangladesh Drinking Water Standard (BDWS), the count of fecal coliform (FC) and total coliform (TC) should be 0 per $100 \mathrm{ml}$ (17).

TABLE 1. Global bottled water market change in consumption by region (2005 - 2009) (5)

\begin{tabular}{|c|c|c|c|c|c|c|}
\hline Regions & $2004 / 05$ & $2005 / 06$ & $2006 / 07$ & $2007 / 08$ & $2008 / 09$ & 5-year CAGR \\
\hline North America & $9.2 \%$ & $8.6 \%$ & $7.9 \%$ & $3.2 \%$ & $1.1 \%$ & $6.0 \%$ \\
\hline Europe & $3.9 \%$ & $4.7 \%$ & $-0.8 \%$ & $0.4 \%$ & $-1.3 \%$ & $1.4 \%$ \\
\hline Asia & $10.1 \%$ & $10.7 \%$ & $11.8 \%$ & $10.3 \%$ & $5.9 \%$ & $9.7 \%$ \\
\hline South America & $5.9 \%$ & $3.5 \%$ & $10.7 \%$ & $7.2 \%$ & $11.4 \%$ & $7.7 \%$ \\
\hline Africa/Mideast/Oceania & $8.1 \%$ & $4.2 \%$ & $6.0 \%$ & $4.7 \%$ & $4.4 \%$ & $5.5 \%$ \\
\hline Total & $7.2 \%$ & $7.1 \%$ & $6.1 \%$ & $4.5 \%$ & $2.7 \%$ & $5.5 \%$ \\
\hline
\end{tabular}

Natural mineral water is characterized by its mineral content, trace elements or other constituents and, where appropriate, by certain other effects. Also, being in its original state, both conditions have been preserved intact because of the underground origin of the water which has been protected from all risk of pollution. The composition, temperature and other essential characteristics of natural mineral water must remain stable at source within the limits of natural fluctuation; in particular, they must not be affected by possible variations in the rate of flow. Mineral waters may be gaseous or non-gaseous. In terms of treatment, disinfections are not allowed. However, filtration or decanting and the addition or removal of carbon dioxide has been authorized (16).

The aim of this study was to determine the microbiological quality of mineral water samples that are commercially available in Bangladesh. A total of 45 bottled mineral water samples were collected from different part of the capital and were analyzed in order to compare their ingredients with existing national and international standards. The public opinion regarding mineral water was also concentrated in the present study. All these finding could be used as a tool to develop necessary policy for the production and availability of safe drinking water.
Not a single brand was found totally free from coliform. The number of TC varied from 7-35 per $100 \mathrm{ml}$ and FC varied from 0-14/00ml. Sample D possessed the maximum number of TC which was 26 $\mathrm{cfu} / 100 \mathrm{ml}$. On the other hand, sample B comprised the bare minimum number of TC with a value of 7 $\mathrm{cfu} / 100 \mathrm{ml}$. In case of $\mathrm{FC}$, sample $\mathrm{D}$ is the most contaminated one with $12 \mathrm{cfu} / 100 \mathrm{ml}$ in number, whereas no FC was found to be present in sample G. Although sample $\mathrm{G}$ indicates absence of FC, it contains $30 \mathrm{TC} / 100 \mathrm{ml}$. On the other hand, for FC count sample E contains $4 \mathrm{cfu} / 100 \mathrm{ml}$. The sample comprises the second highest number of TC which is $20 \mathrm{cfu} / 100 \mathrm{ml}$ (Table 2).

The incidence of total coliforms (TC) and fecal coliforms (FC) are shown in table 3. TC and FC were detected in 14 and 13 bottles out of 45 bottles, respectively. The findings showed that $31.11 \%$ and $28.89 \%$ of the bottled water sampled in the current study contained TC and FC and failed to meet the WHO and BDW standard. Table 4 represents the heterotrophic plate counts (HPC) in bottled mineral water. A total of 31 from 45 examined bottled water showed heterotrophic plate counts (HPC) within a range of 1-500 (cfu/ml). 
TABLE 2. Occurrence of total coliform (TC) and fecal coliform (FC) in sampled bottled water of different brands.

\begin{tabular}{lccc}
\hline Sample ID & $\begin{array}{c}\text { No. of samples } \\
\text { tested }\end{array}$ & \multicolumn{2}{c}{$\begin{array}{c}\text { Indicator bacteria } \\
\text { (no/100ml) }\end{array}$} \\
\cline { 3 - 4 } & & TC & FC \\
\hline A & 5 & 10 & 2 \\
B & 5 & 7 & 4 \\
C & 5 & 18 & 9 \\
D & 5 & 26 & 12 \\
E & 5 & 20 & 4 \\
F & 5 & 13 & 3 \\
G & 5 & 13 & 0 \\
H & 5 & 35 & 14 \\
I & 5 & 11 & 2 \\
\hline
\end{tabular}

A total of 14 from 45 examined bottled water showed heterotrophic plate counts (HPC) greater than $500 \mathrm{cfu} / \mathrm{ml}$. The findings showed that $68.89 \%$ and $31.11 \%$ of the bottled water sampled in the current study contained heterotrophic plate counts (HPC) within a range of $1-500 \mathrm{cfu} / \mathrm{ml}$ and greater than 500 $\mathrm{cfu} / \mathrm{ml}$, respectively and $0 \%$ samples showed less than $1 \mathrm{cfu} / \mathrm{ml}$ heterotrophic plate counts (HPC) .

TABLE 3.Incidence of total coliforms (TC) and fecal coliforms (FC) in sampled bottled water of different brands

\begin{tabular}{cccc}
\hline \multirow{2}{*}{ Sample ID } & $\begin{array}{c}\text { No. of } \\
\text { samples } \\
\text { Tested }\end{array}$ & \multicolumn{2}{c}{$\begin{array}{c}\text { No. (\%) of samples } \\
\text { Positive }\end{array}$} \\
\cline { 3 - 4 } & & TC & FC \\
\hline A & 5 & $3(60)$ & $2(40)$ \\
B & 5 & $1(20)$ & $1(20)$ \\
C & 5 & $1(20)$ & $1(20)$ \\
D & 5 & $1(20)$ & $1(20)$ \\
E & 5 & $1(20)$ & $1(20)$ \\
F & 5 & $2(40)$ & $2(40)$ \\
G & 5 & $1(20)$ & $1(20)$ \\
H & 5 & $2(40)$ & $2(40)$ \\
I & 5 & $2(40)$ & $2(40)$ \\
\hline Overall & 45 & $14(31.11)$ & $13(28.89)$
\end{tabular}

People's perception. Among the respondents, the maximum (64\%) belong to the age group of $12-24$ years, where the lowest (4\%) presenting the age groups of both $37-48$ years and more than 49 years. In terms of educational qualification, the highest numbers (42\%) were undergraduate respondents, followed by Higher Secondary School Certificate (H.S.C.) examination candidates (26\%). On the other hand, lowest (2\%) respondent was found to be passed up to class five (Table 5). During the study period it was observed that, for the most part (34\%) of the respondents were living in Dhaka city for 0 to 10 years, followed by $11-20$ years (26\%) and $21-30$ years (24\%). Only 4\% of the respondents were found to be living in Dhaka city for a period of more than 41 years.
TABLETTABLE 4. Heterotrophic plate counts (HPC) in bottled mineral water.

\begin{tabular}{cc}
\hline & \\
HPC & Number (\%) of positive sample \\
HPC $($ CFU/ml $)<1$ & $0(0.0)$ \\
$1-500$ & $31(68.89)$ \\
$>500$ & $14(31.11)$ \\
Range & $49-973$ \\
Mean & 302 \\
\hline
\end{tabular}

It was observed that, out of 50 respondents, the highest (94\%) number of respondent was overwhelming bottled water in diverse situations for different purpose. A total of $69.2 \%$ respondents said that they had been consuming bottled water for longer period of time because of health consciousness. Scarcity of treated drinking water is another important reason of consumption of bottled water (estimated around 25\%). The other reasons include the easy access to the bottled water at various sources and the ease of portability, as opined by the responded 3.8\% and $1.9 \%$, respectively.

Around $48 \%$ of the total respondents were consuming bottled water for 6-10 years and 24\% of the respondents were found to consume bottled water for a period of $11-15$ years, whereas $22 \%$ of the respondents was consuming bottled water for more than 15 years. About 6\% respondents were also found to consume bottled water for a period of 0-5 years. In the present study, it was observed that the respondents were distinguishing good or bad bottled water on the basis of some criteria. The highest number of respondents (42\%) prioritized taste while choosing good quality bottled water. About $16 \%$ of the respondent also viewed that, clarity and mineral composition of the water, should also be considered as a deterministic criteria to be good quality bottled water. Bangladesh Standards and Testing Institution (BSTI) approval ranked third (14\%), as the criteria for selecting good quality bottled water. Only a few, 8\% and $4 \%$, rely on outlook and popularity as a deterministic criterion to be good quality bottled water, respectively (Table- 5).

A total of $28 \%$ of the respondents considered that the quality of bottled water has been satisfactory, on the contrary to the $26 \%$ of the respondents, who judged that, the quality of bottled water was not that satisfactory. However, the highest (34\%) fraction of the respondents didn't know whether the quality of the bottled water was good or bad. 
TABLE 5. Distribution of the Study subject as per demographic and bottled water consumption.

\begin{tabular}{|c|c|c|c|}
\hline Variables & & $\begin{array}{c}\text { No. of } \\
\text { samples }\end{array}$ & Frequency (\%) \\
\hline \multirow[t]{4}{*}{ Age groups } & $12-24$ & & $32(64)$ \\
\hline & $25-36$ & \multirow{3}{*}{50} & 14(28) \\
\hline & $37-48$ & & 2(4) \\
\hline & $49+$ & & 2(4) \\
\hline \multirow[t]{5}{*}{ Educational Qualification } & Up to Class 5 & & $1(2)$ \\
\hline & S.S.C. & & $4(8)$ \\
\hline & H.S.C & 50 & 13(26) \\
\hline & Undergraduate & & $21(42)$ \\
\hline & Postgraduate & & $11(22)$ \\
\hline \multirow[t]{6}{*}{ Year of Living in Dhaka City } & $0-10$ & & $17(34)$ \\
\hline & $11-20$ & & 13(26) \\
\hline & $21-30$ & & $12(24)$ \\
\hline & $31-40$ & 50 & $6(12)$ \\
\hline & $41-50$ & & $1(2)$ \\
\hline & $51-60$ & & $1(2)$ \\
\hline \multirow[t]{2}{*}{ Consumption of bottled water } & Yes & 50 & $47(94)$ \\
\hline & No & & $3(6)$ \\
\hline \multirow[t]{4}{*}{ Cause of preference for bottled water } & Health consciousness & & $36(69.2)$ \\
\hline & Easy access to bottled water & & $2(3.8)$ \\
\hline & Scarcity of treated drinking water & & $13(25)$ \\
\hline & Ease of Portability & 50 & $1(1.9)$ \\
\hline \multirow{4}{*}{$\begin{array}{l}\text { Bottled water consumption Duration } \\
\text { in years }\end{array}$} & $0-5$ & & $3(6)$ \\
\hline & $6-10$ & & $24(48)$ \\
\hline & $11-15$ & 50 & $12(24)$ \\
\hline & $15^{+}$ & & $11(22)$ \\
\hline \multirow[t]{6}{*}{ Criteria to be a good bottled water } & Clarity & & $8(16)$ \\
\hline & Taste & & 21(42) \\
\hline & Popularity & 50 & $2(4)$ \\
\hline & BSTI approval & & $7(14)$ \\
\hline & Mineral composition & & $8(16)$ \\
\hline & Outlook & & $4(8)$ \\
\hline
\end{tabular}

During the study period, respondents were asked whether they consumed bottled water instead of municipal water, if the quality were highly maintained. Highest (44\%) number of respondents positively reacted, while $32 \%$ of the respondents replied that, they would not do so. A good number (24\%) of respondents were in doubt (Table 6).

During the study period, $46 \%$ respondents opined that the price of bottled water was satisfactory in comparison with the quality they were getting. However, $42 \%$ thought that the price of bottled water was not so satisfactory. It was observed that, $78 \%$ respondents' monthly expenditure on bottled water was less than 300 taka. A total of $10 \%$ respondents were found whose monthly expenditure for buying bottled water was more than 500 taka. During the study period, respondents were asked about the consequence of the empty bottled water after consumption. A total of $23.1 \%$ respondents alleged that they throw the bottles anywhere after consuming the water from the bottles.
A total of $40.4 \%$ respondents replied that they dumped the bottles in dustbins, and $36.5 \%$ said they reused those bottles. Again when the respondents were asked whether the open dumping of empty bottled water could be hazardous for environment, $80 \%$ respondents considered that the empty bottles could be environmentally hazardous due to their non biodegradable plastic content as well as for clogging of drainage system. $4 \%$ respondents were found, who thought it was not so environmentally hazardous, in comparison with $8 \%$ respondents who never thought about such problem. Respondents were also asked whether the contaminated bottled waters were adverse for health or not. A total of $68 \%$ of the total respondents had the realization that the contaminated bottled water would adversely affect human health, whereas about $16 \%$ considered it would not affect the human health, and the same percentage had no idea on this issue. A total of $78.4 \%$ respondents told that they consumed bottled water only when they were outside the home, whereas about $7.9 \%$ respondents were found to consume bottled water every day, while a good number $(13.7 \%)$ of respondents only consumed bottled water in fast food shops and restaurants (Table 6). 
TABLE 6. People's satisfaction, perception and expenditure on bottled water quality.

\begin{tabular}{|c|c|c|c|}
\hline Variables & & No. of samples & Frequency (\%) \\
\hline \multirow{4}{*}{$\begin{array}{l}\text { Perception on bottled } \\
\text { water quality. }\end{array}$} & Satisfactory & \multirow{4}{*}{50} & $14(28)$ \\
\hline & Not satisfactory & & $13(26)$ \\
\hline & Not known & & $17(34)$ \\
\hline & Never Thought About & & $6(12)$ \\
\hline \multirow{3}{*}{$\begin{array}{l}\text { Consumption of bottled water } \\
\text { as substitute of municipal water }\end{array}$} & It Yes & & 22(44) \\
\hline & No & & $16(32)$ \\
\hline & Not known & 50 & $12(24)$ \\
\hline \multirow{4}{*}{ Price of bottled water } & Satisfactory & & $23(46)$ \\
\hline & Not satisfactory & & 21(42) \\
\hline & Not known & & $3(5)$ \\
\hline & Never Thought It & 50 & $3(6)$ \\
\hline \multirow{2}{*}{$\begin{array}{l}\text { Dumping of bottled water after } \\
\text { consumption }\end{array}$} & Throw Anywhere & \multirow[t]{2}{*}{50} & 12(23.1) \\
\hline & $\begin{array}{l}\text { Throw To Dustbin } \\
\text { Reuse It }\end{array}$ & & $\begin{array}{l}21(40.4) \\
19(36.5)\end{array}$ \\
\hline \multirow{2}{*}{$\begin{array}{l}\text { Monthly expenditure on } \\
\text { bottled water }\end{array}$} & Less than 300 taka & \multirow[b]{2}{*}{50} & 39(78) \\
\hline & $\begin{array}{l}300 \text { taka- } 500 \text { taka } \\
\text { More than } 500 \text { taka }\end{array}$ & & $\begin{array}{l}6(12) \\
5(10)\end{array}$ \\
\hline \multirow{2}{*}{$\begin{array}{l}\text { Effect of contaminated bottled } \\
\text { water }\end{array}$} & Adverse & \multirow[b]{2}{*}{50} & 10(8) \\
\hline & $\begin{array}{l}\text { Not so adverse } \\
\text { Not known }\end{array}$ & & $\begin{array}{l}34(68) \\
8(16)\end{array}$ \\
\hline \multirow{4}{*}{$\begin{array}{l}\text { Open dumping of empty } \\
\text { bottled after consumption }\end{array}$} & Hazardous & \multirow{5}{*}{50} & $40(80)$ \\
\hline & Not so hazardous & & 2(4) \\
\hline & Not known & & $4(8)$ \\
\hline & Never thought of it & & $4(8)$ \\
\hline \multirow{3}{*}{$\begin{array}{l}\text { Frequency of consumption } \\
\text { of bottled water }\end{array}$} & Everyday & & $4(7.9)$ \\
\hline & Only outside & \multirow[t]{2}{*}{50} & $40(78.4)$ \\
\hline & Fast food shop & & $7(13.7)$ \\
\hline
\end{tabular}

\section{DISCUSSION}

The objective of this study was to determine the frequency and density of total coliform and fecal coliform in bottled water. The prevalence of total coliform and fecal coliform was investigated in 45 liter bottled water samples collected from different street and shop outlets randomly. This study showed that bottled water sold on the streets and outlets in the Dhaka city, Bangladesh, was of variable microbial safety and quality. The study showed that $31.11 \%$ and $28.89 \%$ of the bottled water sampled in the current study contained TC and FC and failed to meet the World Health Organization (WHO) and Bangladesh drinking water standard (BDWS).

These results are in conformity with Khan (18), who reported the counts of total coliform and fecal coliform in a range of $0-19$ and $0-10 / 100 \mathrm{ml}$, respectively.
Coliforms have long been documented as an appropriate microbial indicator of drinking-water quality (19). In drinking water from municipal supplies, the coliform tests can be used as an indicator of the treatment efficiency and the integrity of the distribution system. Although coliforms may not always be directly associated with the presence of fecal contamination, the presence of coliforms in drinking water suggests the potential presence of pathogenic enteric microorganisms such as Salmonella spp, Shigella spp, and Vibrio cholerae. Coliform bacteria are the only microbiological contamination to be regulated by law in both tap and bottled water all over the world. The presence of total and fecal coliform in bottled water samples has been reported to be due to poor hygienic practices of the producers, failure to wash hands, illiteracy and unhygienic practices of vendors (20). 
The use of bare hands at different stages in the production of the bottled water is a probable source of bacterial contamination. Water for human consumption is required to be free from any bacteria that might pose a health risk. During an outbreak of gastroenteritis in 28 children living in a small neighborhood of Cuernavaca city (Mexico), a survey was performed to evaluate the confidence in coliforms bacteria as sole indicators of portability of drinking waters (21). A primary infection by E. coli and a secondary infection by Pseudomonas aeruginosa were diagnosed in 5 of the children and the drinking water provided by a well was suspected to be a transmission source. According to these authors, a probability of correspondence between the presence of this bacterium and the secondary gastrointestinal infection diagnosed was found pointing towards a need for the inclusion of other microorganisms, one of which may be Pseudomonas aeruginosa, as indicators of health risk associated with drinking water.

It is already mentioned that, potable water should be free from any bacteria that pose a health risk. The presence of heterotrophic pate counts (HPC) more than $500 \mathrm{cfu} / \mathrm{ml}$ and coliforms play a main role in the presence of potential pathogens in drinking water. It can be considered as one of the notable parameter to control the quality of water for human consumption. In this study, $68.89 \%$ and $31.11 \%$ of the bottled water sampled in the current study contained HPC within a range of $1-500 \mathrm{cfu} / \mathrm{ml}$ and greater than 500 $\mathrm{cfu} / \mathrm{ml}$, respectively and $0 \%$ samples showed less than $1 \mathrm{cfu} / \mathrm{ml}$ HPC, indicating a need for regular monitoring of the bottled water by the concerned regulatory authorities.

Up to date, there has been much debate about the health-giving effects of mineral water. Apart from the obvious function of providing liquid to the body, there are no scientific studies that actually show a significant beneficial effect of mineral water on the health (12). While mineral water clearly contains minerals that are, in principle, beneficial for the body, the ability of the body to absorb them from mineral water is not exactly proven. Since natural water is free of any calories, sugar or artificial ingredients, it is certainly better than a sweetened, flavored soft drink (7). There usually being no adverse effects from drinking mineral water, one may therefore drink it just for its fresh taste.

\section{CONCLUSIONS}

The bottled water market has steadily increased over the last decade and is now the largest category of commercial beverage by volume sold in Bangladesh.
A number of people now prefer bottled water rather than tap water for a number of reasons. They may not like the taste, smell, or color of bottled water, but they are continuing the consumption of bottled water in need, irrespective of quality. On the other hand, some people are worried about their health and perceive bottled water as more natural, pure, and a healthier alternative to supplied water by local authorities like WASA and Municipalities. Therefore, ever-increasing demand for bottled water is increasing in Bangladesh, in fact, all around the globe. On the other hand, not all bottled waters have the same qualities. Analysis of 45 bottled water samples in Dhaka, Bangladesh showed a wide assortment of microbial qualities. Generally, bottled water is good for drinking in Bangladesh. However, bottled water quality in Bangladesh needs to be monitored regularly. Indeed, it is a requirement that a tri-monthly monitoring should be carried out on water quality of bottled water of different brands, generally by BSTI and by the Ministry of Health in Bangladesh.

\section{ACKNOWLEDGEMENT}

The authors are thankful to the Department of Microbiology, Stamford University Bangladesh, for lifting the facilities for microbiological experiments and to the Department of Environmental Science of Stamford University Bangladesh. We appreciate the co-operation of Tanvir Hossain during data collection.

\section{REFERENCES}

1. Green, M. \& T. Green. 1994. Water the boom, p. 6-7. In The Good Water Guide. Rosendale Press, London.

2. Hunter, P. R. 1994. Bottled natural mineral water and other bottled waters. Microbiology Europe. 2:8-9.

3. Venter, S. N. 2000. Rapid Microbiological Monitoring Methods: the Status Quo. International Water Associations Blue Pages.

4. AAM (American Academy of Microbiology). 1996. A Global Decline in Microbiological Safety of Water: A Call for Action. American Society of Microbiology, Washington.

5. Beverage Marketing Corporation of New York. 2010. Available at http://www.beveragemarketing.com/globalbottledwater.doc. (Last access on 4th October, 2010).

6. Majumder, A. K. et al. 2010. Assessment of Supplied Water Quality of Sutrapur Thana, Dhaka. J. Environ. Sci. \& Natural Resources. 3(1):61-64.

7. Hem, J. D. 1978. Study and interpretation of the chemical characteristics of natural water, US Geological Survey, $2^{\text {nd }}$ ed. US Government Printing Office, Washington.

8. Deutsch, W. J. 1997. Groundwater geochemistry, fundamentals and applications to contamination. Boca Raton: Lewis, p. 221.

9. Burton, A. C., \& F. Cornhill. 1977. Correlation of cancer death rates with altitude and with the quality of water supply of 100 largest cities in the United States. Journal of Toxicology and Environmental Health. 3:465-478.

10. Burton, A. C., J. F. Cornhill, \& B. Canham. 1980. Protection from cancer by 'Silica' in the water supply of U. S. cities. Journal of Environmental Pathology and Toxicology. 4:31-40.

11. Epstein, S. S., \& M. Zavon. 1974. Is there a threshold for cancer ? p. 54- 62. In D. X. Manners (ed.), Water, Its Effects on Life Quality, International Water Quality Symposium. Water Quality Research Council, Washington. 
12. Kara, E., H. G. Özdilek, \& E. E. Kara. 2004. An investigation on physical, chemical, and bacteriological quality of municipally supplied and well waters of the towns and city centre in the province of Niðde, Turkey. Environmental Monitoring and Assessment. 139:277-285.

13. Buor, D. 2004. Water needs and women's health in the Kumasi metropolitan area, Ghana. Health and Place. 10:85-103.

14. Chapelle, F. H. 2003. Geochemistry of groundwater, p. 425-449. In Holland, H. D., and K. K. Turekian (ed.), Treatise on geochemistry, vol. 5. Elsevier.

15. Lee, S. H., et al. 2002. Surveillance for water borne disease outbreaks in the United States, 1999-2000.

16. Blackburn, B. G., et al. 2004. Surveillance for water borne disease outbreaks associated with drinking water-United States, 2001-2002. MMWR 53(8):23-45.
17. WHO (World Health Organization). 2003. Guidelines for DrinkingWater Quality. 3rd ed. Geneva. http:www.who. who.int/ water_sanitation_health / dwq/en/.

18. Khan, M. R., M. L. Saha, and A. H. M. G Kibria. 1992. A bacteriological profile of bottled water sold in Bangladesh. World Journal of Microbiology and Biotechnology. 8:544-545.

19. WHO (World Health Organization). 1993. Guidelines for drinkingwater quality. 2nd ed. Geneva. http://www.who.int/water_sanitation_ health/.

20. Coroler, L., et al. 1996. Pseudomonas rhodesiae sp. nov., a new species isolated from natural mineral waters. Systematic and Applied Microbiology. 19: 600-607.

21. Victoria, J. and M. Galvan. 2001. Pseudomonas aeruginosa as an indicator of health risk in water for human consumption. Water Sci. Tech. 43(12):49-52. 